\title{
Relationship between symptoms of allergic rhinitis and their severity with specific allergens and duration of allergic rhinitis
}

\author{
Alerjik rinit semptomları ve şiddet dereceleri ile spesifik alerjenler ve \\ alerjik rinitin süresi arasındaki ilişki \\ Fatma Ceyda Akın Öçalan', Müge Özcan², Ramazan Öçalan', Yavuz Fuat Yılmaz², Adnan Ünal² \\ ${ }^{1}$ Department of Otorbinolaryngology, Malatya State Hospital, Malatya, Turkey \\ ${ }^{2}$ Department of Otorbinolaryngology, Ankara Numune Training and Research Hospital, Ankara, Turkey
}

\begin{abstract}
Objective: To determine whether specific allergens induce specific symptoms or not, and whether symptoms and the severity of the symptoms change in the parallel with the increase in the duration of allergic rhinitis or not.

Methods: This trial was conducted through retrospective screening of the data forms of patients who had presented to our ENT-Allergy Unit with allergic symptoms, and diagnosed as allergic rhinitis based on the history, examination and prick test or serum specific $\mathrm{IgE}$ results.

Results: A total of 235 patients were enrolled in the trial. Nasal discharge and postnasal drip were significantly less common in tree allergies, itching and watering of the eyes were more common in grass allergies. Redness in the eyes was significantly less common in weed allergies. Nasal discharge was significantly less common in allergy against animal epithelium and hair. Sneezing and itching/watering of the eyes were significantly less, while hyposmia was more frequently seen in house dust-mite allergies. Comparison of the duration of allergic rhinitis with the frequency of symptoms revealed a statistically significant increase in hyposmia and redness in the eyes in seasonal allergic rhinitis, parallel to the increase in the duration of allergic rhinitis.

Conclusion: We suggest that specific symptomatic treatments directed against the allergen(s) which also shorten duration of allergic rhinitis may be an option in the management of allergic rhinitis and will yield positive outcomes in terms of improved control of the symptoms and hence quality of life of the patients.
\end{abstract}

Key words: Allergic rhinitis, allergen, severity, duration.

Allergic rhinitis (AR) is a common disease affecting nearly $10-25 \%$ of the world population. It is triggered by exposure of the nasal mucosa to allergens, leading to $\operatorname{IgE}$ -

\section{Özet}

Amaç: Spesifik alerjenlerin spesifik semptomları tetikleyip tetiklemediğini, semptomları ve semptomların şiddet derecesini alerjik rinitin süresindeki artışla koşut olarak değişip değiştirmediğini belirlemek.

Yöntem: Bu çalışma hasta veri formlarının retrospektif taranması yoluyla KBB-Alerji Ünitesine alerjik semptomlarla gelen ve hasta öyküsü, muayene, prick testi veya serum spesifik IgE sonuçlarına dayanarak alerjik rinit tanısı konan hastalarda uygulandı.

Bulgular: Çalışmaya toplam 235 hasta alındı. Burun ve geniz akıntısı ağaç alerjilerinde anlamlı derecede daha az, ot alerjilerinde ise gözlerde kaşıntı ve sulanma daha sık görüldü. Gözlerde kızarıklık yabani ot alerjisinde anlamlı derecede daha azdı. Hayvan saç ve epitel döküntülerine karşı alerjide burun akıntısı anlamlı derecede daha düşük oranda görüldü. Ev tozu-akar alerjilerinde aksırık, gözlerde kaşıntı ve sulanma anlamlı derecede daha seyrek, hipozmi ise daha sık gözlendi. Alerji süresinin semptomların sıklığıyla karşılaştırması, mevsimsel alerjik rinitte, alerjik rinitin süresiyle paralel bir biçimde, hipozmi ve gözlerde kızarıklıkta semptomlarında istatistiksel açıdan anlamlı artış olduğunu gösterdi.

Sonuç: Alerjen(ler)e karşı yöneltilen ve alerjik rinitin süresini kısaltan spesifik semptomatik tedavilerin alerjik rinit tedavisinde bir firsat olduğunu, semptomların ve dolayısıyla hastaların yaşam kalitesinin daha iyi kontrol edilmesi sayesinde olumlu sonuçlar vereceğini düşünmekteyiz.

Anahtar sözcükler: Allerjik rinit, allerjen, şiddet, süre.

induced inflammation. It has a negative effect on the quality of life, reduces the productivity, limits active life and triggers the development of sinusitis, otitis and asthma. ${ }^{[1-3]}$
Correspondence: Fatma Ceyda Akın Öçalan, MD. Department of Otorhinolaryngology, Malatya State Hospital, Malatya, Turkey.

e-mail: fceydaakin@gmail.com

Received: May 14, 2013; Accepted: July 21, 2013; Published online: January 29, 2014
Online available at:

www.jmedupdates.org doi:10.2399/jmu.2013003003 QR code: 
In patients with $\mathrm{AR}$, common symptoms such as nasal discharge, nasal itching, sneezing, nasal obstruction and postnasal discharge are accompanied by infrequent symptoms like itching of the palate, ear and the throat, hyposmia and clogged ears. ${ }^{[3]}$ The prevalence of rhinitis in Turkey is around $10 \% .^{[4]}$

$\mathrm{AR}$ is classified as seasonal and perennial based on the time of occurrence and the duration. On the other hand, recent versions of Allergic Rhinitis and its Impact on Asthma (ARIA) guidelines classify AR as intermittent and persistent in terms of duration of symptoms and as mild, moderate and severe in terms of severity of symptoms. The rate of seasonal AR is approximately $80 \%$. The most common allergens in seasonal AR are pollens of trees, grass or weeds. ${ }^{[5]}$ In $20 \%$ of the cases, AR is seen throughout the year and is referred to as perennial rhinitis. Allergens causing perennial AR are in-house allergens, namely house dust mite, mold fungi, epithelium or hair of animals and cockroaches. ${ }^{[6]}$

Though the diagnosis of AR is mainly based on the clinical findings, skin prick test is the most widely used method to determine the responsible allergen. On physical examination, allergic salute, nasal crease, crusting and loss of dermis in the nostrils due to nasal discharge, allergic shiners and Dennie-Morgan lines can be seen. Most authors have stated that a pale, bluish and edematous nasal mucosa is a characteristic finding of AR..$^{[5,7,8]}$

The main objective of this trial was to determine whether specific allergens induced specific and/or more severe symptoms or not, and whether symptoms and the severity of the symptoms change in parallel to the increase in the duration of AR or not. Nasal examination findings are also investigated.

\section{Materials and Methods}

This trial was conducted by retrospective screening of the files of the patients who presented to our ENT-Allergy Unit with allergic symptoms and diagnosed as AR through history, physical examination, and the prick test or by serum specific $\operatorname{IgE}$ results. The exclusion criteria were incomplete data in the forms and negative skin prick test or serum specific IgE results even in the presence of symptoms suggesting AR. The protocol was approved by the Ankara Numune Training and Research Hospital Clinical Trials Evaluation Committee (10/11/2010, Decree No: 2010-053) before initiation of the study.

The following parameters were retrospectively harvested from ENT-Allergy Unit patient data forms: age of the patient, duration of $A R$, symptoms, severity of symptoms, type of allergen based on skin prick test or serum specific IgE, positivity to one or more allergens, timing of the symptoms and findings of physical examination.

In the ENT-Allergy Unit forms, the symptoms were classified as ear-nose-throat (nasal discharge, stuffed nose, itching in nose/throat, sneezing, postnasal discharged, headache, hyposmia), eye (itching/watering of the eyes, redness, redness/swelling around the eyes) and thoracal (coughing, dyspnea, wheezing) symptoms, and each symptom was graded on a scale of $0-4$ based on the severity of the symptom $(0=$ absent, $1=$ mild, $2=$ moderate, $3=$ severe, $4=$ extremely severe).

The duration of $\mathrm{AR}$ was classified into 4 time intervals as 0-5 years, 5-10 years, 10-20 years and over 20 years. The duration of symptoms was assessed in 3 groups as perennial, fall-winter and spring-summer. The types of allergens were classified into 8 subgroups based on the skin prick test or serum specific $\operatorname{IgE}$ values; these subgroups were designated as trees, grass, weeds, fungi, animal epithelium-hair, house dust mites, latex and insects, and those with $\geq 2$ positive results were enrolled in the trial.

On the initial physical examination of the patients, the status of nasal mucosa and presence of secretion were assessed. The findings of the nasal mucosa were classified into 6 subgroups as normal, pale, edematous, hyperemic, hemorrhagic or macerated, while the status of secretion was evaluated in 3 subgroups as no secretion, serous or purulent secretion groups.

Analysis of the data was performed using the SPSS for Windows 11.5 package program (SSPSS Inc., Chicago, IL, USA). Spearman's correlation test, Pearson's chi square test, Fisher's exact chi square test and KruskalWallis test were used where appropriate. A p value $<0.005$ was regarded as statistically significant.

\section{Results}

The data of a total of 235 patients, 161 women $(68.5 \%)$ and 74 men $(31.5 \%)$ with the age range of $14-58$ years, and a mean age of $28.48 \pm 9.23$ years were included in the study. The mean age of the patients at the onset of symptoms was determined as $21.28 \pm 9.16$ years.

\section{Symptoms of the Patients}

The symptoms found in 235 patients with AR have been shown in Table 1 . The most common symptoms were sneezing $(97.4 \%)$, nasal discharge $(94.9 \%)$ and itching in the nose/throat $(90.2 \%)$. 
Perennial symptoms were observed in 95 patients (40.4\%) while 139 cases $(59.1 \%)$ experienced symptoms during the spring-summer period and one patient $(0.4 \%)$ reported symptoms during the fall-winter period.

\section{Findings on Nasal Examination}

Physical examination findings were normal in 161 patients (68.5\%), while mucosal abnormalities were observed in 74 patients (31.5\%). Nasal mucosa was pale in $24(10.2 \%)$; pale and edematous mucosa in 15 (6.4\%), edematous in 15 (6.4\%), hyperemic in 15 (6.4\%), edematous and hyperemic in $1(0.4 \%)$, hemorrhagic and macerated in $1(0.4 \%)$, and macerated nasal mucosa in $1(0.4 \%)$, and hemorrhagic in 2 $(0.9 \%)$ patients, respectively. Secretion was found in the nasal cavity in 78 patients $(33.2 \%)$, while no secretion was observed in 157 cases (66.8\%). There was serous secretion in 58 patients $(24.7 \%)$, purulent secretion in 18 patients (7.7\%), and seropurulent secretion in 2 patients $(0.9 \%)$.

The mucosa exhibited a normal appearance in $62.9 \%$ of the cases with seasonal AR, while pathological findings were observed in $37.1 \%$. In perennial AR, the mucosa was normal in $77.4 \%$ and pathological findings were found in $22.6 \%$ of the patients. Any statistically significant difference was not observed between the mucosal changes and the seasonal or perennial AR ( $>0.05)$. Evaluation of the allergen subtypes and the mucosal findings did not reveal any correlation between them, and no statistically significant difference was determined $(\mathrm{p}>0.05)$.

Statistical analysis revealed that secretion was significantly less severe in cases with house dust-mite allergy $(\mathrm{p}=0.014)$.

\section{Positivity to Specific Allergens}

One allergen was positive in 128 patients (54.5\%), while more than one allergen was positive in 107 cases (45.5\%). Distribution of the cases in terms of the culprit allergens was as follows: grass allergens ( $\mathrm{n}=188$ patients; $80 \%)$, house dust-mite allergens $(n=62 ; 26.4 \%)$, weed allergens $(n=52$; $22.1 \%)$, tree allergens $(\mathrm{n}=50 ; 21.3 \%)$, animal epitheliumhair allergens $(n=38 ; 16.2 \%)$, fungal allergens $(n=19 ; 8.1 \%)$, latex allergens $(\mathrm{n}=7 ; 3.0 \%)$, and insect allergens $(\mathrm{n}=5$; $2.1 \%)$.

\section{The Frequency of Symptoms with Specific Allergens}

The correlation between allergens and frequency of the patients' symptoms revealed a statistically significant negative correlation between tree allergy and frequency of nasal discharge/post nasal discharge $(\mathrm{p}=0.004$ and 0.036 , respec-
Table 1. The frequency of symptoms in the study population.

\begin{tabular}{lc}
\hline Symptom & $\%$ \\
\hline Sneezing & 97.4 \\
Nasal discharge & 94.9 \\
Nasal/throat itching & 90.2 \\
Eye watering/itching & 88.5 \\
Nasal obstruction & 87.7 \\
Postnasal discharge & 80.4 \\
Headache & 73.6 \\
Redness of the eyes & 71.1 \\
Cough & 54 \\
Dyspnea & 50.2 \\
Hyposmia & 46.8 \\
Swelling of the eyes & 38.7 \\
Wheezing & 23 \\
\hline
\end{tabular}

tively). Eye hyperemia was statistically significantly less common in weed allergies $(\mathrm{p}=0.039)$ while nasal discharge was observed to be significantly more common in animal epithelium-hair allergies $(\mathrm{p}=0.029)$. Itching/watering of the eyes were found to be significantly more common in grass allergy ( $\mathrm{p}=0.001)$. Sneezing and itching/watering of the eyes were less common in house dust-mite allergies, while hyposmia was more common; the correlations were found to be statistically significant $(\mathrm{p}=0.043,<0.001$ and 0.018 , respectively) (Table 2).

Table 2. Statistically significant differences in the frequency and the severity of symptoms with specific allergens.

\begin{tabular}{|c|c|}
\hline Symptom & Remarks \\
\hline Sneezing & $\begin{array}{l}\text { Negative correlation with mite allergy }(p=0.043) \text {, } \\
\text { less severe in mite allergy }(p=0.051)\end{array}$ \\
\hline \multirow[t]{3}{*}{ Nasal discharge } & Negative correlation with tree allergy $(p=0.004)$ \\
\hline & $\begin{array}{l}\text { Positive correlation with animal epithelium-hair } \\
\text { allergy }(p=0.029)\end{array}$ \\
\hline & $\begin{array}{l}\text { Less severe in tree allergy }(p=0.001) \text {, and } \\
\text { animal epithelium-hair allergy }(p=0.043)\end{array}$ \\
\hline \multirow[t]{2}{*}{ Eye watering/itching } & $\begin{array}{l}\text { Positive correlation with grass allergy }(p=0.001) \text {, } \\
\text { more severe in grass allergy }(p=0.001)\end{array}$ \\
\hline & $\begin{array}{l}\text { Negative correlation with mite allergy }(p<0.001) \text {, } \\
\text { less severe in mite allergy }(p=0.012)\end{array}$ \\
\hline \multirow[t]{2}{*}{ Postnasal discharge } & Negative correlation with tree allergy $(p=0.036)$ \\
\hline & Less severe in grass allergy $(p=0.018)$ \\
\hline \multirow[t]{2}{*}{ Redness of the eyes } & Negative correlation with tree allergy $(p=0.039)$ \\
\hline & Less severe in weed allergy $(p=0.034)$ \\
\hline Hyposmia & $\begin{array}{l}\text { Positive correlation with mite allergy }(p=0.018) \text {, } \\
\text { more severe in mite allergy }(p=0.00)\end{array}$ \\
\hline
\end{tabular}




\section{Correlation of Specific Allergens with the Severity of the Symptoms}

Nasal discharge was less severe in patients with tree allergy $(\mathrm{p}=0.001)$. In patients with grass allergy, post nasal discharge was statistically significantly less severe, while statistically significantly more severe itching/watering of the eyes were observed in these patients $(\mathrm{p}=0.018$ and 0.001 , respectively). The severity of redness in the eyes was less severe in cases with weed allergy $(\mathrm{p}=0.034)$. No statistically significant correlation was found between fungal allergy and the severity of symptoms ( $p>0.05)$. Nasal discharge was less severe in patients with animal epithelium-hair allergy ( $\mathrm{p}=0.043$ ). Sneezing and itching/watering of the eyes were less severe in cases with house dust-mite allergies, while more severe hyposmia was detected $(\mathrm{p}=0.051,0.012$ and 0.00 , respectively) (Table 2).

Since grass and house dust mite hypersensitivity represent seasonal and perennial allergy in our region, we compared patients with isolated hypersensitivity to those two allergens. Comparison of grass allergy and house dust-mite allergy in terms of the symptoms revealed a statistically significant correlation between grass allergy and itching/watering in the eyes $(\mathrm{p}=0.001)$. Hyposmia was found to be statistically significantly correlated with house dust-mite allergy ( $\mathrm{p}=$ 0.018). Comparison of patients with grass and house dustmite allergies in terms of the severity of symptoms revealed more severe and frequent occurrence of itching/watering of the eyes in cases with grass allergy $(\mathrm{p}=0.025)$, and less severe and less frequent occurrence of sneezing and redness/watering of the eyes with more frequent and severe finding of hyposmia in house dust-mite allergy $(\mathrm{p}=0.001)$.

\section{Correlation of Symptoms with the Duration of AR}

The duration of AR was 0-5 years in 104 cases (44.3\%), 510 years in 77 cases (32.8\%), 10-20 years in 39 cases (16.6\%) and 20 years or over in 15 cases $(6.4 \%)$, respectively. The mean duration of $\mathrm{AR}$ was determined as $7.12 \pm 7.17$ years.

A statistically significant increase was found in the rate of hyposmia and redness in the eyes parallel to the increase in the duration of seasonal $\mathrm{AR}(\mathrm{p}=0.036$ and 0.015 , respectively). However, no such correlation was found in perennial AR ( $>00.05)$.

A statistically significant correlation was found between the overall duration of AR and the severity of redness of the eyes and redness/swelling around the eyes $(\mathrm{p}=0.024$ and 0.033 , respectively). The severity of nasal congestion, redness in the eyes and cough showed a statistically significant increase parallel to the increase in the duration of AR in sea- sonal AR ( $\mathrm{p}=0.048,0.027$ and 0.044 , respectively); however, no such relation was determined in perennial AR $(\mathrm{p}>0.05)$.

The severity of dyspnea and wheezing were found to be increased parallel to the increase in the duration of AR in fungal allergies with a statistically significant difference from other types of allergies ( $\mathrm{p}=0.041$ and 0.042 , respectively). A statistically significant difference was found between the severity of redness/swelling around the eyes and the duration of AR due to house dust-mite hypersensitivity $(\mathrm{p}=0.026)$. However, no statistically significant difference was found between duration of $\mathrm{AR}$ and the severity of symptoms in weed or animal epithelium -hair allergies $(\mathrm{p}>0.05)$.

\section{Discussion}

In a trial conducted on 169 patients with $\mathrm{AR}$, the most common symptoms were specified as sneezing $(79.9 \%)$, serous nasal discharge $(76.9 \%)$, nasal obstruction $(75.7 \%)$, postnasal discharge (55\%) and eye symptoms $(43.8 \%){ }^{[9]}$ Similarly, sneezing (97.4\%) and nasal discharge (94.9\%) were the most common two symptoms in our study followed by itching in the nose/throat (90.2\%), itching/watering of the eyes (88.5\%) and nasal congestion in (87.7\%). Bousquet et al. ${ }^{[5]}$ reported concomitant presence of conjunctivitis in 70-80\% patients with allergic diseases; the corresponding rate in our trial was determined as $88.5 \%$, which is consistent with the literature.

In a Scandinavian trial conducted on 770 patients, the most common allergens were determined as house dust and mite $(44 \%)$, followed by grass, tree and weeds $(30-40 \%) .{ }^{[10]}$ In a trial conducted in Turkey, the most common allergens with frequency in descending order were reported as grasses $(70.5 \%)$, weeds $(45.9 \%)$, house dust mites (35.6-34.9\%) and trees $(25.2 \%){ }^{[11]}$ In the current trial, the most common responsible allergens were grasses $(80 \%)$, house dust mites (26.4\%) and weeds (22.1\%). This diversity may be due to the differences in the distribution of allergens in different countries and even in different regions of the same country.

Papers on AR usually point out that nasal discharge is the main symptom in seasonal AR, while nasal obstruction is the leading complaint in perennial AR ${ }^{[3]}$ However, no studies in the literature, to our knowledge, have investigated the correlation of specific allergens with specific symptoms. Our data objectively revealed more severe and frequent occurrence of itching/watering of the eyes in cases with grass hypersensitivity $(\mathrm{p}=0.025)$ which represents seasonal $\mathrm{AR}$, and less severe and less frequent occurrence of sneezing and redness/watering of the eyes with more frequent and severe hyposmia in house dust-mite hypersensitivity $(\mathrm{p}=0.001)$ which represents perennial AR. 
In the current trial, assessment of each allergen in terms of individual symptoms revealed that nasal and postnasal discharge were less common in patients with tree allergy, itching/watering of the eyes were more common in cases with grass allergy. While redness in the eyes and cough were less frequently seen in patients with weed allergy, and nasal discharge was less common in cases with animal epithelium-hair allergy. However, in patients with house dust-mite allergy, sneezing and itching/watering of the eyes are less and hyposmia more frequently seen with statistically significant difference among groups $(\mathrm{p}<0.05)$ (Table 2). No such correlation was found in fungal allergies. As mentioned above, no reports on this issue have been found in the literature search.

Despite previous papers have reported that symptoms were less severe in perennial AR compared to seasonal AR, and attributed this finding to long-term exposure to low concentrations of the allergens, ${ }^{[7]}$ we have found severe hyposmia more frequently in cases with house dust-mite allergies $(p=0.001)$. However, itching/watering of the eyes were more severe and frequent in grass allergy $(\mathrm{p}=0.025)$, and sneezing and redness/watering of the eyes were less severe and frequent in house dust-mite allergy $(\mathrm{p}=0.001)$. Our results are similar to those of Mark et al. ${ }^{[12]}$ who reported that more than $75 \%$ of the patients with seasonal AR exhibited eye symptoms, and eye symptoms were more common in pollen allergies compared to patients with house dust-mite allergies.

The correlations between the duration of $\mathrm{AR}$ and the frequency and severity of the symptoms have not been studied elsewhere. However it can be hypothesized that a longlasting allergic inflammation may cause chronic changes and fibrosis in the nasal mucosa, especially in the nasal turbinates. In a histopathologic study, Berger et al. ${ }^{[13]}$ have shown that fibrosis in the lamina propria of the turbinates in perennial rhinitis was unresponsive to medical therapy, and this finding was not evident in the compensatory hypertrophic turbinates of the patients with nasal septal deviation. Assessment of the correlation between the duration of $\mathrm{AR}$ and the severity of symptoms in our study demonstrated a significant increase in nasal obstruction in seasonal AR $(\mathrm{p}=0.048)$ as the duration of AR increased, however no such correlation was determined in perennial AR ( $>0.05)$. Moreover, a significant increase in the frequency of hyposmia was observed in seasonal AR as the duration of the disease increased $(\mathrm{p}=0.036)$, but no such relation was found in perennial AR. These findings are important since they may indicate that long-lasting seasonal AR may cause more severe nasal obstruction although in most of the literature nasal obstruction has been reportedly more severe in perennial AR. We believe that these results will guide us in the selection and planning of the long-term treatment of AR and we suggest that with an appropriate treatment plan, we will be able to decrease the frequency and severity of symptoms, which show an increase in parallel with the increase in the duration of AR.

Regarding the relation of the symptoms with the duration of $\mathrm{AR}$, we also found that, with prolonged exposure $\mathrm{AR}$ caused a significant increase in the rate of dyspnea in fungal allergies $(p=0.045)$. Therefore, one must be alert for the development of asthma in long-lasting AR due to fungal allergens.

Another important finding of our study relates to the physical examination findings in AR. The results of previous trials showed that serous nasal discharge, edematous turbinates and blue or pale mucosa were observed in the nasal cavity of patients with typical $\mathrm{AR} \cdot{ }^{[1,12]}$ In the current trial, no secretion was found in the nasal cavity in $66.8 \%$ of the patients, while serous secretion was observed in $24.7 \%$ of them. More importantly, nasal mucosa was normal in $68.5 \%$ of the patients, while a pale mucosa was found only in $10.2 \%$ and edematous mucosa in $6.4 \%$ of the patients. In contrary to literature, our findings showed that edematous and pale mucosa is seen only in $6.4 \%$ of the patients. These findings suggest that examination of the nasal mucosa may be normal in a great majority of patients, and hence, the "nasal examination findings" must be revised in most of the textbooks. Statistical evaluation revealed that there was no correlation between the seasonal or perennial character of the allergens and the status of the mucosa/secretion; however, we determined a significantly lower rate of secretion in patients with allergy against house dust mites.

Since the two most common allergens in our trial were grass and house dust-mites, we compared these two allergens. Itching/watering of the eyes was more common and more severe in cases with grass allergy. On the other hand, sneezing and itching/watering of the eyes were less common, while hyposmia was more common and more severe in cases with house dust-mite allergy.

\section{Conclusion}

In conclusion, we suggest that specific symptomatic treatments directed against the allergen(s) which shorten the duration of AR may be an option in AR and will yield positive outcomes in terms of the better control of the symptoms and hence the patients' quality of lives.

Conflict of Interest: No conflicts declared. 


\section{References}

1. Salib RJ, Drake-Lee A, Howarth PH. Allergic rhinitis: past, present and the future. Clin Otolaryngol Allied Sci 2003;28:291-303.

2. Guadano EM, Serra-Batlles J, Meseguer J, Castillo JA, de Molina $\mathrm{M}$, Valero A, et al. Rupatadine $10 \mathrm{mg}$ and ebastine $10 \mathrm{mg}$ in seasonal allergic rhinitis: a comparison study. Allergy 2004;59:766-71.

3. Skoner DP. Allergic rhinitis: definition, epidemiology, pathophysiology, detection, and diagnosis. J Allergy Clin Immunol 2001;108(1 Suppl):S2-8.

4. Kendirli GS, Altintas DU, Alparslan N, Akmanlar N, Yurdakul Z, Bolat B. Prevalence of childhood allergic diseases in Adana, Southern Turkey. Eur J Epidemiol 1998;14:347-50.

5. Bousquet J, Van Cauwenberge P, Khaltaev N; Aria Workshop Group; World Health Organization. Allergic rhinitis and its impact on asthma (ARIA). J Allergy Clin Immunol 2001;108(5 Suppl):S147-334.

6. Von Mutius E, Weiland SK, Fritzsch C, Duhme H, Keil U. Increasing prevalence of hay fever and atopy among children in Leipzig, East Germany. Lancet 1998;351:862-6.
7. Blaiss M. Current concepts and therapeutic strategies for allergic rhinitis in school-age children. Clin Ther 2004;26:1876-89.

8. Peat JK, Li J. Reversing the trend: reducing the prevalence of asthma. J Allergy Clin Immunol 1999;103(1 Pt 1):1-10.

9. Saleem T, Khalid U, Sherwani UU, Ghaffar S. Clinical profile, outcomes and improvement in symptoms and productivity in rhinitic patients in Karachi, Pakistan. BMC Ear Nose Throat Disord 2009;9:12.

10. Holopainen E, Salo OP, Tarkiainen E, Malmberg H. The most important allergens in allergic rhinitis. Acta Otolaryngol Suppl 1979;360:16-8.

11. Yasan H, Aynali G, Akkuş Ö, Doğru H, Özkan M, Şahin M. Alerjik rinitten sorumlu alerjen profilinin değişimi ve semptomlarla korelasyonu. KBB Forum (Ankara) 2006;5:158-60.

12. Mark S, Dykewicz MD, Daniel L Hamilos MD. Rhinitis and sinusitis. J Allergy Clin Immunol 2009;125:103-15.

13. Berger G, Gass S, Ophir D. The histopathology of the hypertrophic inferior turbinate. Arch Otolaryngol Head Neck Surg 2006;132:588-94.

This is an open access article distributed under the terms of the Creative Commons Attribution-NonCommercial-NoDerivs 3.0 Unported (CC BYNC-ND3.0) Licence (http://creativecommons.org/licenses/by-nc-nd/3.0/) which permits unrestricted noncommercial use, distribution, and reproduction in any medium, provided the original work is properly cited.

Please cite this article as: Akın Öçalan FC, Özcan M, Öçalan R, Yılmaz YF, Ünal A. Relationship between symptoms of allergic rhinitis and their severity with specific allergens and duration of allergic rhinitis. J Med Updates 2013;3(3):116-121. 